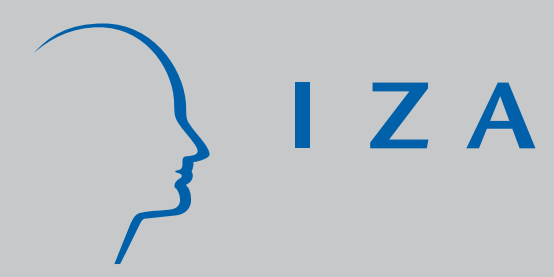

IZA DP No. 2274

1.5 Generation Internal Migration in the US:

Dispersion from States of Immigration?

Mark Ellis

Jamie Goodwin-White

August 2006 


\title{
1.5 Generation Internal Migration in the US: Dispersion from States of Immigration?
}

\author{
Mark Ellis \\ University of Washington, Seattle \\ Jamie Goodwin-White \\ University of Southampton \\ and IZA Bonn
}

Discussion Paper No. 2274

August 2006

IZA

P.O. Box 7240

53072 Bonn

Germany

Phone: +49-228-3894-0

Fax: +49-228-3894-180

Email: iza@iza.org

\begin{abstract}
Any opinions expressed here are those of the author(s) and not those of the institute. Research disseminated by IZA may include views on policy, but the institute itself takes no institutional policy positions.

The Institute for the Study of Labor (IZA) in Bonn is a local and virtual international research center and a place of communication between science, politics and business. IZA is an independent nonprofit company supported by Deutsche Post World Net. The center is associated with the University of Bonn and offers a stimulating research environment through its research networks, research support, and visitors and doctoral programs. IZA engages in (i) original and internationally competitive research in all fields of labor economics, (ii) development of policy concepts, and (iii) dissemination of research results and concepts to the interested public.
\end{abstract}

IZA Discussion Papers often represent preliminary work and are circulated to encourage discussion. Citation of such a paper should account for its provisional character. A revised version may be available directly from the author. 


\section{ABSTRACT}

\subsection{Generation Internal Migration in the US: Dispersion from States of Immigration?}

The issue of immigrant spatial concentration and the possibilities for immigrant dispersion through migration features in at least three interrelated debates about immigration. First, the ethnic enclave literature centers on the question of whether spatial concentration improves or harms the economic well-being of immigrants. Second, spatial assimilation theory links immigrant relocation away from residential enclaves to socioeconomic gains. Although framed at an intra-urban scale, we suggest that similar assimilation logics infuse thinking and expectations about immigrant settlement and spatial mobility at other scales. And third, immigrant clustering links to anxieties about the threats posed by non-European origin newcomers to the traditional cultural fabric of the nation. In the current wave of immigration, research on questions of settlement geography and spatial mobility has so far been restricted to the first generation. But as the current wave of immigration matures there is a growing population of adults who are the children of immigrants. This paper investigates the migration behavior of these adult children, specifically the 1.5 generation, seeking to answer the question of whether they will remain in the states in which their parent's generation settled or move on. It also assesses whether the out-migration response of the 1.5 generation in states of immigrant concentration is similar to that of their parent's generation or the US-born population.

JEL Classification: J61

Keywords: $\quad 1.5$ generation, internal migration, immigrant concentrations, spatial assimilation

Corresponding author:

Jamie Goodwin-White

Division of Social Statistics

Southampton Statistical Sciences Research Institute

University of Southampton

Southampton SW2 4QB

United Kingdom

E-mail: J.Goodwin-White@soton.ac.uk 


\section{Introduction}

One of the distinctive features of contemporary immigration to the US is that the foreignborn population concentrates in a handful of states (e.g. US Census Bureau 2000). Whilst there is some indication of a shift in this pattern to new destination states in the south and west (e.g. Singer 2004), the vast majority of the children of immigrants, both 1.5 and $2^{\text {nd }}$ generation, are coming of age in a limited number of traditional gateway states, most notably California, New York, Texas and Florida. How these descendents of the current wave of immigration will fare in America's post-industrial economy, with its ever-widening gap between rich and poor, is the rightful subject of much debate among scholars of immigration. Surrounding this issue is the important question of location: will the adult children of immigrants be content to stay in the states and localities in which their parent's generation settled or will they move on to greener pastures to stake their claim to the American dream? In this paper we begin to answer this question through an analysis of the interstate migration of the adult 1.5 generation.

Despite early prognoses that the children of immigrants would decline into an urban underclass (Gans 1992, Massey 1995, Portes and Zhou 1995), more recent investigations have cautiously surmised they will surpass the educational and occupational attainments of their parents (Hirschman 2001, Zhou 2001, Farley and Alba 2002). Such assessments note the complications of race and nativity, however, stressing that intergenerational progress will be slower for some racial and nativity groups than others. In so doing, there is continuing reference to segmented assimilation hypotheses with their claim that immigrant adaptation is contingent upon race and context of settlement (Rosenbaum and Friedman 2001). However, with the exception of Zhou's (2001) findings that second generation occupational and educational 
progress depends on urban context, there has been little empirical consideration of the ways in which location might matter for the children of immigrants.

This is doubly curious given the historical preoccupation of immigration research with immigrants' mobility and settlement patterns, and the focus on the role of distinctive ethnic communities in immigrant assimilation. It seems that interrogation of the geography and spatial mobility of later generations would be of interest in three regards. First, the neighborhood integration of immigrants and the US-born has been a continuing focus of spatial assimilation research (Massey 1985; Massey and Denton 1988; Alba, Logan, and Crowder 1997; Alba, Logan et al 1999), one that could be easily extended to the residential patterns of the adult children of immigrants. Second, concern at a regional level with the territorial politics of immigrant mobility and settlement would seem to necessitate questions of where subsequent generations live as well (Frey 1995, 1996; Ellis and Wright 1998; Wright and Ellis 2001). Third, internal migration has traditionally been an important condition for socio-economic advancement in America's geographically mobile society. In the 1980 s for example, annual mobility rates in the United States were approximately double those found in Europe and Japan, a difference frequently attributed to the relative openness of housing and labor markets in the US (Long 1988, 1991). On first blush, it seems likely that the socio-economic progress of the adult children of US immigrants will be influenced by these same deregulated market conditions, facilitating their migration away from centers of immigration.

This paper explores the empirical foundations for these arguments by focusing on the interstate migration behavior of the adult 1.5 generation, defined as immigrants who arrive in the US under 10 years of age. The 1.5 generation is a group for whom we have sufficiently large samples for an in-depth analysis of migration behavior relative to two key comparison groups: first generation immigrants and the US-born. In particular, two questions underpin the analysis. 
Does the internal migration behavior of the 1.5 generation resemble that of the US-born population or is it more like that of the adult foreign-born? And are 1.5 generation adults leaving the regions of the country where their parents settled? Answers to these questions will reveal the extent to which the adult children of immigrants are moving away from states of immigration, and whether their migration responses to origin economic and social conditions is like that of the US-born as might be expected under a process of assimilation.

\section{Space, Migration and Immigrant Incorporation in the US}

The geography and spatial mobility of the foreign-born have been important features of debates about immigrant wellbeing and incorporation in the United States for well over a century. One of the earliest statements on this subject is by Jacob Riis' (1890) in his famous expose of poverty in New York, How the Other Half Lives. When he colorfully suggested that "a map of the city, colored to designate nationalities, would show more stripes than on the skin of the zebra and more colors than the rainbow" he invoked a link between immigrant concentration and deprivation that persists to this day (Riis 1890:20). Pro and anti-immigrant advocates in the next three decades argued back and forth about whether immigration problems were simply a matter of insufficient geographical dispersion from ports of entry and select industrial cities where immigrants clustered (e.g. Hall 1907, Warne 1916). And although these arguments were often couched in terms of economic efficiency and aiding the process of cultural absorption, questions of the threat posed by spatial concentrations of "others" in America's cities were not far from the surface. Some nineteenth century nativists went as far as to conclude that America's largest cities contained the two biggest threats to their idealized Jeffersonian nation: industrialization and alien labor (Higham 1988). US resident Jewish groups were so sensitive to issues of clustering that they actively tried to disperse newly arrived 
Eastern European Jews from urban ghettos for fear that mass spatial concentration would stoke the fires of American anti-Semitism (Glazier 1998).

Contemporary debates about immigrant concentration contain more than a faint echo of these arguments. At the scale of states and regions, assertions of "flight" from areas of immigration and ensuing "demographic balkanization" conjure up images of unbridgeable cultural fissures between immigrant groups who hail largely from Asia and Latin America and US-born whites (Frey 1995, 1996; cf Ellis and Wright 1998). Although these claims predate Samuel Huntington's (2004) most recent incendiary book, it is this work which most clearly articulates an anxiety about how immigrant cultural diversity, specifically that supplied by Latinos, is eroding the cultural foundations of the Anglo-American mainstream. His earlier book, The Clash of Civilizations (1997), also spoke of these ideas, predicting conflict not only between cultures outside the US but also within it. In particular, Clash includes a map of US counties in which the US Census projects non-white majorities in the first few decades of the twenty-first century (a largely contiguous belt of counties in the West and Southwest). In Huntington's view, it is the map's projection of regional clusters of non-white dominance which raises alarm bells about immigration's effect on the cohesiveness of the nation.

In less inflammatory fashion, contemporary immigration scholars have spilled much ink arguing over the form of ethnic enclaves/economies and their implications for immigrant welfare. Original formulations of the enclave outlined it as an ill-defined spatial concentration which bounded the existence of immigrant economic, social, and cultural life, providing the necessary support for newcomers to progress economically (e.g. Wilson and Portes 1980, Portes 1981, Portes and Manning 1986). As such, the enclave hy pothesis is a provocative assertion that immigrant segregation from the mainstream (no matter how defined) improves their socioeconomic position. From the beginning, the appropriate space in which to assess this 
concentration (e.g. combinations of census tracts, whole cities, metropolitan area) and whether it referred to place of residence, work or both, has never been clear (c.f. Sanders and Nee 1987; Portes and Jensen 1987; Zhou and Logan 1989). In exasperation at this analytical morass, some scholars rejected the idea that ethnic enclaves could, or should, be spatially bounded and pushed for investigations of ethnic networks and industrial concentrations under the rubric of ethnic economies (e.g. Light 1994, Waldinger 1993). But empirical studies which adopt this focus most often bound their investigations of ethnic economies within individual metropolitan areas, thereby delimiting an appropriate spatial scale of analysis implicitly.

Unlike ethnic enclave research, the study of immigrant residential geography has been investigated mostly at the intra-urban scale, building largely on the frameworks emanating from spatial assimilation theory. As articulated by Massey(1985), spatial assimilation theory posits that cultural adaptation and socioeconomic advancement by immigrants would propel their moves from highly-concentrated central city enclave locations to less ethnically-isolated suburbs. As a result of this relocation, they would experience further acculturation and gain further opportunities for the structural assimilation of their children, mainly through proximity to the US-born. In this classical framework, spatial assimilation is very much a local process. Accordingly, most empirical investigations of spatial assimilation theory analyze immigrant residential mobility across intra-urban census tracts (e.g. Alba et. al. 1999, Alba Logan and Stults 2000, Logan, Alba, and Leung 1996, Logan, Alba and Zhang 2002), but some use the larger public-use microdata areas to take advantage of individual microdata (Allen and Turner 1996).

The formulaic representation of immigrants who initially reside in concentrated neighborhoods of co-ethnics and disperse as they integrate into "American" social space has often translated, unfortunately, into measurement of immigrant residential distance from US 
whites, as if that were some singularly "American" reference group with singularly "American" residential patterns unmarked by earlier immigration experience, or by histories of race, class and their making in place (Wright and Ellis 2000, Wright, Ellis and Parks 2005, but see Logan 2005 for an alternative view). In the sense that theory creates normative expectations, the idea of spatial assimilation underpins jeremiads about immigrants whose mobility and residence do not follow theorized expectations of ethnic deconcentration.

At least three perspectives offer alternatives to such a pernicious interpretation of immigrant socio-spatial behavior. First, segmented assimilation theory emphasizes the constraints that make it difficult for those at the bottom of the racial hierarchy to translate socioeconomic gains into less segregated housing outcomes (see, for example, Alba, Logan, and Leung 1994, Rosenbaum and Friedman 2001). Second, Zelinsky and Lee's (1998) heterolocalism, which suggests that immigrant ethnic bonds can remain strong even in dispersed residential patterns, disrupts the simple linear association between neighborhood geography and assimilation at the heart of spatial assimilation theory. And third, many immigrants now move directly to suburban locations, bypassing the stereotypical central city enclave to cluster, at least in some instances, in prosperous middle-class ethnoburbs (e.g. Li, 1998).

Neighborhood scale research on race and ethnicity has a long pedigree in US social science dating back to the genesis of the Chicago School in the 1920s. This helps explain why most contemporary research on the connections between space and immigrant incorporation occur at the intra-urban scale. Yet there are other equally important spatial scales at which to observe immigrant adjustment to host society which get less attention from scholars. For example, the rate of mixed partnership formation between immigrants and non-co-nationals is a measure of immigrant spatial incorporation within households, even though most literature on outpartnering does not treat the household as a spatial scale in the same ontological manner as 
spatial assimilation theory treats neighborhoods (e.g. Bossard 1939, Kalmijn 1993, Alba 1995, Bean and Stevens 2003; but compare White and Sassler 2000, Ellis and Wright 2005, Ellis, Wright and Parks 2005). There is also a small but growing research tradition connecting assimilation and space at metropolitan and state scales through analyses of immigrant location and subsequent internal migration (e.g. Bartel 1989, Kritz and Nogle 1994, Chiswick and Miller 2004). Bartel (1989: 387-88), for instance, hypothesizes that immigrants should move to cities with smaller percentages of co-ethnics as they assimilate.

In recent papers, Frey and Liaw (2005a, 2000b) are even more explicit about the connection between assimilation and immigrant internal migration. They argue that immigrant gains in human capital gains should generate migration to states and localities where fewer coethnics live. On initial inspection, this scale-jumping extension of spatial assimilation theory to immigrant internal migration, which is how Frey and Liaw label their approach, seems benign in its implications. But, as in the case of its original intra-urban formulation, the spatial assimilation framework may lead to simplistic judgments of an immigrant group's assimilative progress based on the extent of their migration-led dispersion from ethnic concentrations. Prominent immigration skeptics certainly take the view that dispersion through internal migration is a barometer of a group's willingness to shed the bonds of ethnic attachment and assimilate into American life (e.g. Kennedy 1996, Huntington 2004).

As in the intra-urban case, a segmented assimilation perspective offers a useful corrective to this questionable interstate dispersion-as-assimilation logic by highlighting the enduring importance of own-group association, especially for those unfavorable racialized in US society. If we accept segmented assimilation's premise, today's non-European immigrants and their descendents are unlikely to stray far from regions where their ethnic resources are strong and which they perceive to be tolerant. Somewhat ironically, research on the settlement geography 
of earlier European immigrant groups and their descendents is consistent with this idea. For example, Lieberson and Waters (1987) found locational persistence through the twentieth century in the regional geographies of groups who mostly had arrived in the US by the turn of the twentieth century or earlier.

Such persistence is also evident among the first generation of today's immigrants whose inter-state out-migration propensity is lowest from states where immigrants concentrate (Kritz and Nogle 1994). There is no information, however, about the migration behavior of the adult children of these immigrants. Spatial logics derived from assimilation theory, such as those articulated by Bartel (1989)and Frey and Liaw (2005), implies that these later generations will disperse from first generation sites of concentrated immigrant settlement. In this view, the USborn children of immigrants, or immigrants who arrived as young children, should have considerably more experience in the US and exposure to a US educational system than the foreign-born who arrived in adolescence or older. Consequently, the immediate descendents of today's immigrants should have less need of the social capital found in ethnic concentrations to make their way in the world. Moreover, with their qualifications and socialization to US norms, they should have greater access and attraction to opportunities wherever they exist in the US. Alternatively, segmented assimilation suggests that ethnic networks and persistent racialization may continue to play an important part in limiting the mobility of immigrants and their descendents.

If historical experience is any guide, predictions of dispersal by the descendents of today's immigrants are unlikely to be borne out. For example, an investigation into the characteristics of the immigrant population and its descendents based on 1920 census data noted "an indisposition on the part of this second generation to travel very far from their foreign-born parents and kinsmen" (Carpenter (1927: 43). In light of the distinctive racial and ethnic 
composition of contemporary immigrant populations, and in recognition of the the responses predicted by segmented assimilation theory, it seems improbable that the descendents of contemporary immigrants will leave present states of immigrant concentration in significant numbers. The remainder of this paper is dedicated to investigating this expectation empirically through an analysis of the interstate migration propensities of three distinct adult groups: foreign-born, US-born and the 1.5 generation.

\section{Data and Preliminary Analysis}

The preceding discussion raised uncertainty about the possibility that the adult children of immigrants will disperse away from immigrant concentrations. The problem with investigating this question empirically is the inability to identify $2^{\text {nd }}$ or later generations from the large sample data sets needed for migration research. It is possible to identify the $2^{\text {nd }}$ generation proper from CPS data on parental birthplace, but these data provide inadequate sample sizes for our multivariate analysis. The identification of the 1.5 generation in the 5\% 2000 PUMS data affords a suitable proxy, with a significantly larger sample size that makes it possible to consider the effect of numerous covariates, such as race, and generates a longer 5-year (rather than 1-year in the CPS) migration question. We differentiate the 1.5-generation population from the remainder of the foreign-born population by age at arrival: following Perlmann and Waldinger (1997) and the work of Ruben Rumbaut we define the 1.5 group as immigrants who entered the US before they were ten years of age. The foreign-born as we define them are thus those immigrants who arrived later in life.

To start, we examine state variation in the percentage foreign-born and 1.5 generation (Figure 1). The states are ranked by the sum of these percentage shares.The distributions of 
percent foreign-born and 1.5 generation are highly correlated $(\mathrm{r}=0.86)$, which is not surprising given that many of the 1.5 generation reside in the homes of their immigrant parents.

Next, we examine the raw inter-state five-year mobility rates of immigrants, the 1.5 generation, and US-born adults from the 2000 PUMS. ${ }^{1}$ Overall, 1.5 generation adults are more likely to undertake inter-state moves between 1995 and 2000 than either US-born or foreignborn adults. We are particularly interested, especially given the literature on the negative relationship identified between nativity concentration and internal migration, in the importance of initial residence in a state with a high concentration of immigrants. States designated as immigrant concentrations have both high percentages of immigrants and large populations and include California, Texas, New York, New Jersey, and Florida (this definition excludes Hawaii and Nevada - two states with high percentages of immigrants but small populations).

Figure 2 shows that the foreign-born and the 1.5 generation are much more likely to move out of state if their origin state does not have a high concentration of immigrants. While immigrant, 1.5 generation, and US-born individuals all have similar rates of out-migration from immigrant states, the foreign-born and 1.5 generation population have much higher mobility rates from states without significant immigrant concentrations. Specifically, living in an immigrant state reduces the probability of migration for the 1.5 generation by nearly half, a slightly greater proportional reduction than for the foreign-born. Overall, these descriptive results cast doubt on expectations of dispersion by the adult children of immigrants.

\section{Models}

\footnotetext{
${ }^{1}$ Foreign-born and second generation individuals have at least one foreign-born parent. Individuals in these nativity group comparisons are at least 18 years of age. As in our models in the next section, individuals residing in Alaska, Hawaii, and the District of Columbia are excluded from this analysis.
} 
To compare these migration rates more effectively requires standardization of group differences by appropriate control variables. Accordingly, we estimated a series of binary logistic regressions to compare interstate mobility rates among the US-born, foreign-born, and the 1.5 generation using the five percent sample of the 2000 PUMS. To reiterate, our foreignborn category is differentiated from the 1.5 generation category in that the latter arrived in the US prior to their $10^{\text {th }}$ birthday.

Two sets of models are estimated: an initial set comparing foreign-born and 1.5 generation individuals in which foreign-born Hispanics are the reference category, and a second set comparing US-born and 1.5 generation individuals in which US-born whites are the reference category. This allows us, in the first instance, to answer questions of mobility and the importance of ethnic concentration therein for the 1.5 generation relative to foreign-born Hispanics, the group it seems that much current debate takes as its concern, especially with regard to questions of geographic concentration. In the second instance we compare the 1.5 generation with US-born whites, the largest US-born group, to see whether there exist residual differences in mobility between these two populations.

This two pronged modeling strategy allows us to measure as clearly as possible differences between the migration behavior of the 1.5 generation and a reference group that is either foreignborn or US-born. We rejected an alternative modeling strategy that relies on a single three group model because this procedure allows only one reference group and greatly increases the number of interaction effects needed to replicate the two group model specifications, substantially complicating interpretation. For all models, the sample includes heads of household at least 23 years of age in 2000 (18 at the start of the risk period for a move), who are not on active-duty military service or living in group quarters. The dependent variable in all models is whether or not an individual made an inter-state move between 1995 and 2000. All specifications include 
covariates measuring race/ethnicity (coded Hispanic, white, black, Asian, and other) ${ }^{2}$, age (in decadal cohorts), completed education, ${ }^{3}$ number of persons in the family, and dummy indicators for marital status, gender, and self-employment. Each set of the two group models is a sequence of five logit specifications that add additional groups of covariates and interactions.

We chose race and ethnic categories rather than national origin to differentiate groups for two reasons. First, racial and ethnic categories allow us to group diverse national origin populations that concentrate in particular states into a small number of standardized groups. Of course, this standardization glosses over considerable national origin variability within racial and ethnic categories across regions. For example, Hispanic populations in Florida, New York, and California are quite distinct in national origin composition and social position, although the rapid growth of the Mexican population in east coast cities is slowly reducing these regional differences. Our second rationale has to do with the external racialization process that immigrants and especially their children experience within the US. Newcomers slot into America's ethnic and racial hierarchy so that in many walks of social life their labeling and treatment by others will be significantly captured by these racial and ethnic groupings. While we do not have precise expectations for the migration patterns of specific racial or ethnic groups, race and ethnicity have been so consistently important in the geography of immigrant and second generation settlement that it is reasonable to expect this will continue to be the case (Lieberson and Waters 1987).

The basic 1.5 generation/foreign-born model also include a dummy variable for recent (1990 or later) arrivals among the foreign-born. This cohort variable only operates on the

\footnotetext{
${ }^{2}$ We used a simple cross-walk scheme to collapse multiracial race categories into single race groups. Those who reported as black/white were categorized as black, and Asian/white as Asian. Hispanics are anyone responding to the Hispanic ethnicity variable. Other includes those not reporting as Hispanic, black, Asian or white, or reporting multiple races other than black/white and Asian/white.

${ }^{3}$ Less than high school, high school diploma or GED, some college, or at least a bachelor's degree are the four categories here.
} 
foreign-born population because the sample's age requirements exclude the possibility that any of the 1.5 generation will be in the recent arrival cohorts: all members of the 1.5 generation in the 2000 Census arrived before 1987, most before 1980.

The first logit specification includes the basic covariates just described. Models 2-5 add an immigrant origin concentration variable, which is a logged continuous measure of the proportion of the origin state that is foreign-born. ${ }^{4}$ This concentration variable is interacted with 1.5 generation status in order to examine the differential effect of concentration on mobility for the 1.5 generation. Model 3 introduces variables measuring origin state employment conditions, including percentage employment growth and manufacturing jobs as a share of all employment. ${ }^{5}$ Much of the new employment over this period would have been in the burgeoning service sector, and we did not include a service jobs as percent of employment as this indicator would partially replicate the employment growth effect. As such, we have controlled in these models for both an "old economy" historically immigrant sector (manufacturing) and newer job growth. We also tested variables for origin unemployment, and various housing affordability measures but these were insignificant. Models 4-5 include 2-way interactions of race/concentration, education/concentration, and nativity/race, and 3-way interactions of nativity/race/concentration as covariates. ${ }^{6}$ Descriptive statistics on key covariates for the US-born, foreign-born and the 1.5 generation are shown in Table 1.

\section{Foreign-born/1.5 Generation Models}

\footnotetext{
${ }^{4}$ Values of less than $1 \%$ are rounded up to 1.

${ }^{5}$ State employment growth is averaged over five years from 1990-95 in order to be exogenous to migration. The percent of jobs in manufacturing is from 1995. These variables are mean-centered, and the persons in family variable is centered at 1 , so as to facilitate interpretation of coefficients.

${ }^{6}$ 3-way interactions including education were tested and found to be insignificant and so not included in the final models presented here.
} 
Results from the models comparing the 1.5 generation with immigrants who arrived later in life (referred to throughout this section as foreign-born) are reported in Table 2. We show five logit specifications illustrating the effects of additional main and interaction effects. In the reduced model 1 , we can see that the 1.5 generation is significantly more likely to undertake an inter-state move than immigrants who arrived as adults (about 6\% more likely). Other covariates display expected relationships, such that interstate migration declines with age and household size, increases with education, and is less likely for women and the self-employed.

The crux of our analysis is the origin state foreign-born concentration variable (logcon) introduced in model 2. After controlling for the individual-level variables in the reduced model 1, concentration has significant negative effects, such that increasing immigrant concentration at origin deters out-migration. These effects are even more pronounced for the 1.5 generation than for the immigrants who arrived as adults (the reference category), as indicated by the coefficient on the 1.5 con interaction term. Moreover, with these two variables included, the size of the 1.5 generation main effect increases considerably from model 1 , meaning that 1.5 generation interstate mobility is much higher from states with the lowest concentrations of immigrants than from states with high percentages of immigrants. This confirms earlier speculations that the 1.5 generation are more likely to stay put in the states in which their parents generation settled.

The inclusion of state-level employment growth and percent manufacturing employment has minimal impact on the main effect for concentration, indicating that the negative effects of concentration on mobility are robust to origin economic conditions. However, while the 1.5 generation effects (main and interacting with concentration) maintain sign and magnitude in model 3, they are no longer significant, partly because in this and subsequent models standard errors are clustered on origin state to account for the state measurement of economic conditions. 
Thus, our major findings from models 1-3 are: 1) that concentration at origin significantly deters out-migration, and more so for the 1.5 generation than for immigrants who arrived as adults, and 2) that this effect is robust to the inclusion of state-level economic indicators and individual demographic variables such as age and education.

Model 4 begins to explore how these immigrant concentration effects vary by racial group and educational status through the addition of second-order interactions of race and education with concentration. Concentration has no differential effect on white or black migration propensity relative to the Hispanic reference category, but it does reduce the migration rate for Asians. The interactions between immigrant concentration and education are stronger, showing that concentration reduces the probability of an interstate move for the most educated. Admittedly, these negative interactions are insufficient to cancel out the positive main effects of education; thus the highly educated still remain the most mobile group at all levels of immigrant concentration. Nevertheless, the cumulative impact of these education effects generates a smaller variance in interstate mobility rates by education in states with the highest concentration of immigrants. Model 4 also includes interactions between 1.5 generation status and race, which show that 1.5 generation blacks and Asians are more mobile than their foreign-born counterparts.

Model 5 unpacks the effects of immigrant concentration on the mobility of the 1.5 generation by group with three way interactions. As this interaction gets closest to the issue at the heart of this paper, and as it is our richest specification, we devote most of our comments to the parameter estimates from this final model. In general, considerations of origin concentration and its interactions with generational status in this model substantially undermine the idea of 1.5 generation dispersal. This statement may seem surprising after glancing at the main effect of 1.5 generation status, for this coefficient is considerably more positive in model 5 than in the 
previous four specifications. However, the interaction between 1.5 generation and immigrant concentration is a good deal more negative than in the other models. Thus at high values of immigrant concentration the interstate mobility of the 1.5 generation is considerably lower than for the foreign-born reference category.

The mixture of two and three-way interactions in model 5 makes it hard to discern group differences in the relationship between concentration and mobility. Cumulating all relevant main and interaction effects at a range of levels of immigrant concentration and charting the resulting probabilities of interstate mobility is much better for this purpose. Figure 3 reports such probabilities calculated with values of most of the independent variables held constant at the reference category or mean, allowing only 1.5 generation/foreign-born status, race, and concentration to vary. As such, Figure 3 charts estimates of the interstate migration probability for single, high-school educated, men in their thirties who are not self employed. ${ }^{7}$ Although our concentration variable is continuous, the probabilities in this figure are calculated at state-level concentrations that follow the actual distribution of these values in 2000: California is $18 \%$ foreign-born, NY is $15 \%$ foreign-born, and the other states previously specified as immigrant states TX, FL, and NJ, also AZ and NV) range from 9-12\% foreign-born.

We can see that living in a state immigrant concentration reduces the propensity to migrate across state lines for the 1.5 generation and foreign-born in all groups. In fact, the 1.5 generation have an extraordinarily high propensity to leave states with extremely low concentrations of immigrants. Indeed, for 1.5 generation Hispanics, blacks, and Asians (and foreign-born Asians) in origin states that are $1 \%$ immigrant (zero log concentration), the probabilities of migration

\footnotetext{
${ }^{7}$ By simply replacing coefficients, we could have examined, for example, married self-employed women in their fifties. These reference categories were chosen for illustrative purposes so as to compare the most-mobile prime working-age population. Since gender and marital status have negative effects on migration in our models these probabilities would be about $15-25 \%$ lower for similar married women. Figure 4 compares similar men with a bachelors degree in order to illustrate the effects of education.
} 
range between .25 and .4. At higher levels of concentration, 1.5 generation Asians and blacks and their foreign-born counterparts share equally low out-migration rates; and 1.5 generation Hispanics actually become less likely to move than their foreign-born co-ethnics. Keep in mind that these charts compare migration probabilities for the 1.5 generation relative to immigrants who arrived as adults before 1990. When compared to adult immigrants who arrived after 1990, the relative immobility of 1.5 generation Hispanics becomes even more pronounced in states with high percentages of immigrants.

Figure 4 charts probabilities of interstate mobility under the same conditions as in Figure 3 but for those with a bachelors degree instead of a high school diploma. As already noted, the main effects of education indicate an unsurprising result: those with more years in school are more likely to move; but the interactions of education with immigrant concentration moderate this difference. Figure 4 reveals how much these combined effects influence interstate mobility rates at various levels of immigrant concentration for the 1.5 generation and foreign-born with a bachelors degree. A comparison of Figure 4 with Figure 3 shows that, for all groups, both the 1.5 generation and the foreign-born with a BA degree have higher interstate mobility than the equivalent with a high school education. But just as for those with a high-school education, interstate migration rates for foreign-born and 1.5 generation BA recipients are lowest from the highest immigrant concentrations. Further, the retaining effect of concentration appears stronger for the 1.5 generation who have a BA degree than those with a high school education, as evidenced by the steeper concentration gradients in this chart relative to Figure 3 . This suggests that the most-educated members of the 1.5 generation view states with high immigrant concentrations as providing the best (or most accessible or preferred) labor market opportunities, just as the 1.5 generation with a high school education do. 


\section{US-born/1.5 Generation Models}

The foreign-born/1.5 generation models suggest that members of these two groups are less mobile when resident in states with high immigrant concentrations. This result holds even for those with the most education; thus it is unlikely that the socioeconomic advance of the 1.5 generation will initiate their interstate dispersal. However, these models do not answer the question of whether the migration response of the 1.5 generation to immigrant concentration differs from that of the US-born. It may be that the outmigration response of the well-educated 1.5 generation is no different than the behavior of the equivalently educated (and racialized) USborn who reside in states of immigrant concentration. In this case, 1.5 generation dispersal is not only unlikely but also contrary to the assimilative convergence in migration behavior between the descendents of immigrants and the US-born. Accordingly, the next set of models compare the interstate migration behavior of the 1.5 generation to the US-born, taking US-born whites as the reference category. The models follow the same patterns of variable inclusion as the foreign-born/1.5 generation models discussed above. As before, we are most interested in the coefficients of the fully-specified model 5, but there are useful insights to be gleaned from the sequenced introduction of variables in the preceding models

Model 1's basic specification shows no difference in migration propensity between the 1.5 generation and the US-born. This similarity masks significant differences between these two groups in the effect of immigrant concentration on migration rates. For example, in model 2 the significant positive 1.5 generation coefficient indicates greater interstate mobility by the 1.5 generation in states with a logged immigrant concentration value of zero (immigrant concentrations are $1 \%$ or less). With increasing origin concentration, however, this migration rate differential reverses: the mobility of the US-born rises slightly while that of the 1.5 generation falls (see coefficients on logcon and 1.5con). 
Model 4 interrogates group and education differentials in the migration response to concentration through a series of two-way interactions. In this model the main effects of race capture group differences in migration propensity at the lowest level of immigrant concentration. Asians and Hispanics are extremely likely, relative to whites, to leave low concentration states. With increasing immigrant concentration, however, the interactions of race and concentration show that the mobility of Hispanics and Asians diminishes considerably whereas that for whites increases (the latter measured by the logcon coefficient in the presence of interaction terms between race and concentration). This does not necessarily mean that whites are more likely to leave high immigrant concentrations than Asians or Hispanics. The only way to determine if this is the case is to calculate migration probabilities for these groups using realistic values of immigrant concentration - a task we turn to after the remaining discussion of the coefficients. Model 4 also interacts education with immigrant concentration and, as in the foreign-born/1.5 generation models, the college educated are least likely to move from states with high immigrant concentrations.

Model 5 introduces interactions to measure differences in the effect of immigrant concentration on migration for 1.5 generation race groups relative to their US-born counterparts. To disentangle these interaction effects more thoroughly and illustrate the effect of variable levels of immigrant concentration in the origin state on the mobility of the 1.5 generation and the US-born we calculated migration probabilities by race and nativity group, much as we did for the foreign-born/1.5 generation models (Figure 5). Again, these probabilities are estimated for single, high-school educated, not self-employed men in their thirties; other variables are set at their means. The charts vary calculations using the same range of immigrant concentration as in the foreign-born/1.5 generation migration probabilities 
US-born whites and blacks look very similar in their response to immigrant concentration: the greater the proportion foreign-born in the origin, the higher the probability of undertaking an interstate move. US-born Asians and Hispanics, however, react like their foreign-born counterparts in being less likely to move from states with high immigrant concentrations. Reactions to concentration also vary among 1.5 generation groups. There appears to be a minimal effect of concentration on the migration propensity of 1.5 generation whites. Black 1.5 generation mobility diminishes when they are resident in high immigrant states. This decline is even stronger for 1.5 generation Asians and Hispanics.

For Asians and Hispanics, then, the migration response of the 1.5 generation closely resembles that of their US-born co-ethnics; regardless of generation, both groups appear to be least mobile from states in which immigrants cluster. The situation for 1.5 generation blacks and whites is more complicated because US-born members of their groups are larger and more distinctive from recent immigrants than is the case for Asians and Hispanics. Most notable is the disjuncture between the reactions of 1.5 generation blacks and US-born blacks to low immigrant concentrations, although both share the same outmigration rate from the highest immigrant concentrations. The difference between them at low immigrant concentrations may reflect their variable response to residence in the American south where US-born blacks are numerous and have a long residential association but immigrants, including foreign-born blacks, are thin on the ground.

Figure 6 charts migration probabilities for the 1.5 generation/US-born with a BA degree. Unlike the results for high school graduates, these probabilities show consistent trends across all groups with outmigration probabilities diminishing as immigration concentration rises. At low levels of immigrant concentration, 1.5 generation whites, blacks, Hispanics are more mobile than their US-born counterparts. But at the highest levels of concentration, outmigration rates are 
virtually uniform and low across all groups. Thus for highly educated members of the 1.5 generation, low rates of mobility from states with high immigrant concentrations conform to the migration behavior of the US-born in the equivalent race group. As such, in terms of interstate mobility, it seems that the highly educated 1.5 generation have assimilated to the responses of their US-born equivalents but that this migration behavior is inconsistent with expectations of their interstate dispersion.

\section{Conclusions}

We began this paper by asking whether the descendents of today's immigrants would disperse from states of immigration in their efforts to make their way in American society. Based on our investigation of the interstate migration behavior of the 1.5 generation, the answer to this question is probably not: regardless of education, members of the 1.5 generation of all race groups appear to be least likely to undertake an interstate move when resident in a state with high concentrations of immigrants.

At first blush, the 1.5 generation appear to following the pattern established by their parent's generation in which concentrations of co-nationals or co-ethnics are either attractive from a cultural familiarity perspective, or because they provide pools of group-specific social capital. That both the highly educated foreign-born and 1.5 generation are less likely to migrate when residing in immigrant state concentrations suggests that education will not diminish these factors. This reluctance is consistent with what Boyd (2000) calls a "rejection of educationbased mobility by immigrant offspring." 
The comparisons between the US-born and 1.5 generation, however, tell a different story. For the high-school educated there is some disparity in the response to immigrant concentrations between US-born and 1.5 generation whites and blacks. For those with a BA, however, the response across generations for all race groups is uniform: the lowest rates of outmigration are from states with the highest concentrations of immigrants. This calls into question the notion that the highly-educated 1.5 generation are cleaving to the locations in which their parents settled for reasons of cultural familiarity or access to group specific capital alone. For if the highly-educated US-born who reside in the same places are reacting the same way, it suggests that states with high concentrations of immigrants have the sorts of job opportunities, or access to jobs, that make it attractive for them to stay. Consequently, regional persistence by the descendents of today's immigrant populations is likely, much as it was for the descendents of the previous wave of immigration a century ago (Lieberson and Waters 1988).

One consequence of this persistence is that it is probable that the regions in which today's 1.5 and $2^{\text {nd }}$ generations are coming of age will also be where they will be employed for most, if not all, of their working lives. From a supply-side perspective, the labor market careers of these immigrant descendents will depend, in part, on their educational achievements and skills acquisition. But local demand conditions will also matter a great deal, as the job successes of the 1.5 and $2^{\text {nd }}$ generation will hinge on the structure and fortunes of the regional economies in which they remain, and on the receptivity of local employers to them. These are uncertain processes whose outcomes will only reveal themselves with time and careful analysis. Existing research on immigrant and ethnic economies, however, suggests some useful questions to begin these investigations. These include whether ethnic job niching and rates of entrepreneurialism will persist across generations, and if and how the shape and ranking of ethnic and job queues will 
change as the 1.5 and $2^{\text {nd }}$ generation make up an increasing fraction of local labor supply (see Light and Bonacich 1988, Waldinger 1996).

On its face, the similarity in interstate migration behavior between the 1.5 generation and the US-born should help reduce anxiety about the assimilability of today's immigrants and their descendents. But although these convergent migration behaviors are a clear sign of immigrant adjustment to US society they are at odds with the prevailing logic of the spatial dispersion-as assimilation model because they imply sustained regional immigrant concentrations. This logic will be hard to disrupt because its origins are deeply rooted in a common social scientific epistemological practice: the tendency to read off social relations directly from spatial patterns. Moreover, those who perceive regional concentrations of immigrants as worrisome for future national coherence are unlikely to be cheered by the similar migration responses of the 1.5 generation and the US-born in those concentrations. In the British context, Vron Ware (2001) has argued that the challenge posed by uneven ethnic geographies is to get people to accept the idea that the nation is multiethnic no matter the local composition of the population. Given that internal migration is unlikely to even out immigration's mark on the US ethnic landscape, and in light of the anxieties this geography invokes, this substantial challenge also confronts the US.

Finally, the analysis in this paper only investigates half of the migration story: the propensity to move. It is still unknown where the 1.5 generation moves to and whether their destination choices favor immigrant concentrations. If their moves are primarily to these clusters then their concentration will intensify even further over time in a handful of immigrant rich states. As with the out-migration models, this concentration through migration may not just be distinctive to the 1.5 generation but also replicated in the pattern of origin-destination flows of the US-born, especially by the highly educated. The next step is to analyze these 
flows with destination choice models, comparing the choices of the 1.5 generation to the USborn and foreign-born much as we have done in this paper for out-migration propensities. 


\section{References}

Alba. R.

1995. “Assimilation's Quiet Tide.” The Public Interest. 119 (1): 3-18.

Alba, R., Logan, J., and Leung, S.

1994 "Asian Immigrants in American Suburbs: An Analysis of the Greater New York Metropolitan Area" In Suburban Communities: Change and Policy Responses. Research in Community Sociology, Volume 4. Ed. Mark Baldassare. Greenwich, CT: JAI Press.

Alba, R., Logan, J., Stults, B., Marzan, G. and Zhang, W

1999 "Immigrant groups in the suburbs: A reexamination of suburbanization and spatial assimilation," American Sociological Review 64: 446-60.

Alba, R., Logan, J., and Crowder, K.

1997 "White ethnic neighborhoods and spatial assimilation: The Greater New York region, 1980-1990," Social Forces 75: 883-912.

Alba, R., Logan, J. and Stults, B.

2000. “The Changing Neighborhood Contexts of the Immigrant Metropolis," Social Forces, 79(2): 587-621. 
Allen, J. and Turner, E.

1996. "Spatial Patterns of Immigrant Assimilation," The Professional Geographer, 28(2): 140155.

Bartel, A.

1989 “Where Do the New US Immigrants Live?” Journal of Labor Economics, 7 (4): 371-391.

Bean F. and Stevens G.

2003. America's Newcomers and the Dynamics of Diversity. New York: Russell Sage.

Borjas, G.

1999 Heaven's Door: Immigration Policy and the American Economy. Princeton: Princeton University Press.

Bossard, J.H.

1939. "Nationality and Nativity as Factors in Marriage.: American Sociological Review. 4 (6): 792-98.

Boyd, M.

2002 "Educational Attainments of Immigrant Offspring: Success or Segmented Assimilation?" International Migration Review 36: 1037-1060.

Carpenter, N. 
1927. Immigrants and their children, 1920. A study based on census statistics relative to the foreign born and the native white of foreign or mixed parentage. Government. Printing Office: Washington DC.

Chiswick, B.R. and Miller, P.W.

2004. "Where Immigrants Settle in the United States." Journal of Comparative Policy Analysis 6 (2): 185-197.

Ellis, $\mathrm{M}$ and Wright, $\mathrm{R}$.

1998. "The Balkanization Metaphor and the Analysis of US Immigration." Annals of the Association of American Geographers_88: 686-698

2005. "Representations of Difference: Mapping Immigrants or Immigrant Households." Forthcoming Proceedings of the National Academy of Sciences.

Ellis, M., Wright R. and Parks, V.

2005. "The Immigrant Household and Spatial Assimilation: Partnership, Nativity and Residential Location.” Forthcoming Urban Geography.

Farley, R. and Alba, R.

2002 "The new second generation in the United States," International Migration Review 36: 669-701.

Frey W. H., and Liaw K.L. 
2005a Interstate Migration of Hispanics, Asians, and Blacks: Cultural Constraints and Middle Class Flight. Report 05-0575. Population Studies Center, University of Michigan.

2005b. Explaining Migration within the United States: The Impact of Immigrant Minorities and Blacks. Brookings Institution.

Gans, H. H.

1992 "Second-Generation Decline: Scenarios for the Economic and Ethnic Futures of the Post1965 American Immigrants," Ethnic and Racial Studies, 15:173-192.

Glazier, J.

1998. Dispersing the ghetto. Ithaca, NY: Cornell University Press.

Hall, P.F.

1907. Immigration. New York: Henry Holt and Company.

Higham $\mathrm{J}$.

1988 Strangers in the land: patterns of American nativism, 1860-1925. $2^{\text {nd }} e d$. New Brunswick, NJ.: Rutgers University Press.

Hirschman, C.

2001 "The Educational Enrollment of Immigrant Youth: A Test of the Segmented-Assimilation Hypothesis," 38(3): 317-336.

Huntington, S.P. 
1997. The Clash of Civilizations and the Remaking of World Order. New York: Simon and Schuster.

2004. Who We Are: The Challenges to America's National Identity. New York: Simon and Schuster.

Kalmijn, M.

1993. "Spouse Selection Among the Children of European Immigrants: A Study of Marriage Cohorts in the 1960 Census.” International Migration Review. 27 (1): 51-78.

Kennedy, D.M.

1996. "Can We Still Afford to Be a Nation of Immigrants?" The Atlantic Monthly, November. Volume 278, No. 5; pages 52-68.

Kritz, M. M., and Nogle, J. M.

1994 “Nativity Concentration and Internal Migration among the Foreign-Born,". Demography, 31 (3): 509-524.

Li, W.

1998. "Anatomy of a New Ethnic Settlement: The Chinese Ethnoburb in Los Angeles," Urban Studies, 35 (3): 479-501.

Lieberson, S. and M. Waters

1987 "The Location of Ethnic and Racial Groups in the United States," Sociological Forum, 2(4): 780-810. 
1988. "From Many Strands : Ethnic and Racial Groups in Contemporary America" New York : Russell Sage Foundation.

Light, I.

1994. "Ethnic Economies. In Handbook of Economic Sociology. Ed. N Smelser and R Swedberg. New York: Russell Sage Foundation:

Light I. and Bonacich E.

1988. Immigrant entrepreneurs: Koreans in Los Angeles, 1965-1982. Berkeley and Los Angeles: University of California Press.

Logan, J.R.

2005. Re-Placing Whiteness: Where's the Beef? City and Community, 4 (2): 137-142.

Logan, J.R, Alba, R., and Leung, S. 1996.

“Minority Access to White Suburbs: A Multiregional Comparison,” Social Forces, 74 (3): 851881.

Logan J.R, Alba R., and Zhang W. 2002.

"Immigrant Enclaves and Ethnic Communities in New York and Los Angeles," American Sociological Review, 67(2): 299-322.

Long, L.H. 
1988. Migration and Residential Mobility in the United States. New York: Russell Sage Foundation

1991. Residential mobility differences among developed countries. International Regional Science Review, 14, 133-47.

Logan, J., Alba, R., and Leung, S., 1994 "Minority access to white suburbs: A multiregion comparison," Social Forces 74: 851-81.

Massey, D.

1986 “The Settlement Process Among Mexican Migrants to the United States” American

Sociological Review 51: 670-85.

1995 "The New Immigration and Ethnicity in the United States," Population and Development Review, 21(3):631-649.

Massey, D. and Denton, N.

1993 American Apartheid. Cambridge: Harvard University Press.

Perlmann, J. and R. Waldinger

1997 "Second Generation Decline? Children of Immigrants, Past and Present -- A

Reconsideration," International Migration Review, 31(4):893-922. 
Portes, A.

1981. “Modes of Structural Incorporation and Present Theories of Immigration” In Global Trends in Migration. Ed M.M Kritz, C.B. Keely, and S.M. Tomasi. Staten Island, NW: CMS Press.

Portes, A. and Manning, R.

1986 “The Immigrant Enclave: Theory and Empirical Examples” In Competitive Ethnic Relations. Ed. J. Nagel and S. Olzak. Orlando, Fl: Academic Press.

Portes, A. and Jensen, L.

1987. "What's an Ethnic Enclave? The Case for Conceptual Clarity", American Sociological Review 52: 768-70.

Portes, A. and Zhou, M.

1995 "Divergent Destinies: Immigration, Poverty and Entrepreneurship in the United States." In Poverty, Inequality and the Future of Social Policy. Ed. K. McFate, R. Lawton and W. J. Wilson. New York: Russell Sage Foundation.

Riis, J.

1890. How The Other Half Lives. New York: Scribners. 
Rosenbaum, R. and S. Friedman

2001 "Immigration, Assimilation, and Inequality Differences in the Locational Attainment of Immigrant and Native-Born Households with Children in New York City" Demography, 38 (3): 337-348.

Singer, A.

2004. The Rise of New Immigrant Gateways. Washington D.C.: Brookings Institution Living Cities Census Series.

Waldinger, $\mathrm{R}$.

1993. “The Ethnic Enclave Debate Revisited.” International Migration Review 17: 444-52. 1996. Still The Promised City? African Americans and New Immigrants in Postindustrial New York.. Cambridge, MA: Harvard University Press.

Ware, V.

2001. "Perfidious Albion: Whiteness and the International Imagination" In The Making and Unmaking of Whiteness. Ed. B. Brander, E. Klinenberg, IJ Nexica, M Wray. Durham, NC: Duke University Press

Warne, J.W.

1916. The Tide of Immigration. New York: D. Appleton and Company. 
White, M.J., and Sassler, S.

2000. “Judging Not Only by Color: Ethnicity, Nativity, and Neighborhood Attainment," Social Science Quarterly. 81(4): 997-1013.

Wilson, K. and Portes A.

1980. "Immigrant Enclaves: An Analysis of the Labor Market Experiences of Cubans in Miami. American Journal of Sociology 88: 295-319.

Wright, R. and Ellis, M.

2000 "Race, Region, and The Territorial Politics of Immigration in the United States," International Journal of Population Geography, 6 (3): 197-211.

Wright, R, Ellis, M and Parks, V.

2005. "Re-Placing Whiteness in Spatial Assimilation Research", City and Community, 4 (2): 111-136.

Zelinsky W., and Lee B.

1998. Heterolocalism: An Alternative Model of the Sociospatial Behavior of Immigrant Ethnic Communities, International Journal of Population Geography 4: 281-298.

Zhou, M.

2001 "Progress, Decline, Stagnation? The New Second Generation Comes of Age." In Strangers at the Gates: New Immigrants in Urban America. Ed. R. Waldinger. Berkeley: University of California Press. 
Zhou, M, and Logan, J

1989. "Returns on Human Capital in Ethnic Enclaves: New York City's Chinatown. American Sociological Review 54: 809-20. 
Table 1: Summary of Covariates by Nativity

$\begin{array}{llll} & \text { US-born } & \text { Foreign-born } & \mathbf{1 . 5} \text { Generation } \\ \mathrm{N} & 895,788 & 85,550 & 11,697 \\ \% & 90.2 \% & 8.60 \% & 1.20 \%\end{array}$

$\begin{array}{llll}\text { Race \% } & & & \\ \text { White } & 83 & 43 & 45 \\ \text { Hispanic } & 4 & 26 & 36 \\ \text { Black } & 11 & 7 & 4 \\ \text { Asian } & 1 & 3 & 3 \\ \text { Other } & 2 & 3 & 3\end{array}$

Age \%

$20 \mathrm{~s}$

$30 \mathrm{~s}$

$40 \mathrm{~s}$

$50 \mathrm{~s}$

$60 \mathrm{~s}$

$70 \mathrm{~s}$

$\begin{array}{lll}9 & 8 & 20 \\ 20 & 25 & 31 \\ 23 & 25 & 21 \\ 18 & 18 & 12 \\ 13 & 12 & 3 \\ 18 & 12 & 13\end{array}$

\section{Education \%}

$\begin{array}{llll}<\text { High School } & 17 & 41 & 20\end{array}$

$\begin{array}{llll}\text { High School } & 30 & 18 & 21\end{array}$

$\begin{array}{llll}\text { Some College } & 22 & 13 & 22\end{array}$

$\begin{array}{llll}\text { BA+ } & 31 & 29 & 37\end{array}$

$\begin{array}{llll}\begin{array}{l}\text { Other Variables } \\ \text { Self-Employed \% }\end{array} & 10 & 12 & 10 \\ \text { Married \% } & 55 & 65 & 56 \\ \text { Female \% } & 34 & 29 & 35 \\ \text { Persons (Mean) } & 1.4 & 1.8 & 2.3 \\ & & 64 & 58 \\ \text { \% in Concentrated State* } & 30 & & \\ \begin{array}{l}\text { Interstate Migration Rate } \\ \text { from concentrated state* }\end{array} & 7.4 & 7.4 & 7.7 \\ \text { from other state } & 7.6 & 11.6 & 13.8\end{array}$

* includes CA, NY, NJ, FL, TX,. This is for summary purposes only, and is not used in the logit models. 
Table 2. Foreign-born/1.5 Generation Logit Models of Interstate Migration, 1995-2000

\begin{tabular}{|c|c|c|c|c|c|}
\hline Variable & Model 1 & Model 2 & Model 3 & Model 4 & Model 5 \\
\hline 1.5 Generation & $.0596519 \star \star \star$ & $.135646 * \star \star$ & .1294039 & -.0705726 & $.6745257 \star \star \star *$ \\
\hline \multicolumn{6}{|c|}{ Race (reference= Hispanic) } \\
\hline White & $.1737513 \star \star \star$ & $.0473708 * \star \star$ & .0080595 & -.0518349 & .1254699 \\
\hline Black & $.1578904 * \star \star$ & $.1033927 * \star *$ & .0505208 & .0025205 & .1007695 \\
\hline Asian & $.4512072 * \star \star$ & $.3885945 * \star \star$ & $.3609741 * \star \star$ & $.7718573 * \star \star$ & $.8927288 * \star \star$ \\
\hline Other & $.470602 * \star \star$ & $.4156859 \star \star \star$ & $.3778119 * \star \star$ & 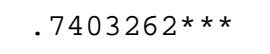 & $.8373925 * \star \star$ \\
\hline \multicolumn{6}{|c|}{ Age Cohort (reference $=30 \mathrm{~s}$ ) } \\
\hline $20 \mathrm{~s}$ & $.3175186 * \star \star$ & $.2980921 * \star \star$ & 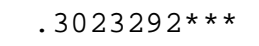 & $.2945175 * \star \star$ & $.2955541 * \star \star$ \\
\hline $40 s$ & $-.5381307 * \star \star$ & $-.5348387 \star \star \star$ & $-.535893 * \star \star$ & $-.5226269 * \star \star$ & $-.5230886 * \star \star$ \\
\hline $50 \mathrm{~s}$ & $-1.012665 * \star \star$ & $-1.014946 * \star \star *$ & $-1.018569 * \star \star$ & $-1.006851 * \star \star$ & $-1.006759 * \star \star$ \\
\hline $60 s$ & $-1.118903 * \star \star$ & $-1.11579 * \star \star$ & $-1.120602 \star \star \star$ & $-1.111032 * \star \star$ & $-1.111406 * \star \star$ \\
\hline $70 \mathrm{~s}$ & $-1.367431 * \star \star$ & $-1.366017 \star \star \star$ & $-1.369351 * \star \star$ & $-1.341499 * \star \star$ & $-1.341661 * * *$ \\
\hline \multicolumn{6}{|c|}{ Education (reference= HS Diploma) } \\
\hline$<\mathrm{hs}$ & $-.0487605 * \star \star$ & $-.0453347 \star \star$ & -.0336865 & $-.2730096 * \star \star$ & $-.2432639 \star \star \star$ \\
\hline College & $.1188642 \star \star \star$ & $.1344814 * \star \star$ & $.1459885^{\star}$ & $.4919545 \star \star \star$ & $.4806174 \star \star \star$ \\
\hline $\mathrm{BA}+$ & $.6516897 \star \star \star$ & $.6349712 * \star \star$ & $.639137 * \star \star$ & $1.271179 * \star \star *$ & $1.260079 * \star \star$ \\
\hline \multicolumn{6}{|l|}{ Other Variables } \\
\hline Self-Employed & $-.3605071 * \star \star$ & $-.3428032 * \star \star$ & $-.3391784 * \star \star$ & $-.3390579 * * *$ & $-.3391887 * \star \star$ \\
\hline Married & .0066384 & -.0088566 & -.0101778 & -.0124462 & -.0123158 \\
\hline Female & $-.1695624 * \star \star$ & $-.1449321 * \star \star$ & $-.1508149 * \star \star$ & $-.1527836 * \star \star$ & $-.1535466 * \star \star$ \\
\hline \# persons in hhold & $-.1315756 * \star \star$ & $-.1221465 * \star \star$ & $-.1219458 * \star \star$ & $-.1218387 \star \star \star$ & $-.12177 \star \star \star$ \\
\hline 90 s arrival & $.3488986 * \star \star$ & $.3075828 * \star \star$ & $.3061859 \star \star \star$ & $.3160688 * \star \star$ & $.3180376 * \star \star$ \\
\hline \multicolumn{6}{|l|}{ Origin Variables } \\
\hline Logcon & & $-.40138 * \star \star$ & $-.4324828 * \star \star$ & $-.2104582 \star \star \star$ & $-.164238 * \star$ \\
\hline $1.5 \cdot \operatorname{con}$ & & $-.0490389 * \star \star$ & -.0442873 & -.0194654 & $-.3477179 * \star \star$ \\
\hline Empchange & & & $-.0173618 * *$ & -.015499 & $-.0154306 * \star$ \\
\hline$\%$ manufacturing & & & -.4983916 & $-.6813079 * \star$ & -.6844742 \\
\hline \multicolumn{6}{|c|}{ 2nd-order race-concentration-interactions } \\
\hline White-con & & & & .0466545 & -.0356249 \\
\hline Black·con & & & & .0112994 & -.0307192 \\
\hline Asian·con & & & & $-.208231 * \star$ & $-.261525 * \star \star$ \\
\hline Other·con & & & & $-.1905019 * \star$ & $-.2320505 * \star \star$ \\
\hline \multicolumn{6}{|c|}{ 2nd-order education-concentration interactions } \\
\hline$<\mathrm{HS} \cdot \mathrm{con}$ & & & & $.0978931 * \star \star$ & $.0843786 \star \star \star$ \\
\hline College·con & & & & $-.1623033 * \star$ & $-.1572798 * \star \star$ \\
\hline BA.con & & & & $-.3141376 * \star \star$ & $-.3093113 * * \star$ \\
\hline \multicolumn{6}{|c|}{$2^{\text {nd }}$-order 1.5 generation-race interactions } \\
\hline 1.5·White & & & & .1100905 & $-.9304038 * \star *$ \\
\hline 1.5·Black & & & & $.3187903 * \star \star$ & -.3255962 \\
\hline 1.5·Asian & & & & $.3503555 * \star *$ & $-.4696855^{\star \star \star \star *}$ \\
\hline 1.5.Other & & & & $.503398 * \star \star$ & -.157054 \\
\hline \multicolumn{6}{|c|}{$3^{\text {rd }}$-order 1.5 generation-race-concentration interactions } \\
\hline 1.5·White-con & & & & & $.4872738 * \star \star$ \\
\hline 1.5·Black·con & & & & & $.2810487 * \star \star$ \\
\hline 1.5·Asian·con & & & & & $.3658603 * \star \star$ \\
\hline 1.5·Other.con & & & & & $.2867858 * \star \star$ \\
\hline Constant & $-1.959868 * \star \star *$ & $-1.045523 * \star *$ & $-.979295 * * \star$ & $-1.45198 * \star \star *$ & $-1.558546 * * x$ \\
\hline
\end{tabular}

${ }^{*} p<0.1 ;{ }^{* *} p<0.05 ;{ }^{* *} p<0.01$ 
Table 3. US-born/1.5 Generation Logit Models of Interstate Migration, 1995-2000

\begin{tabular}{|c|c|c|c|c|c|}
\hline Variable & Model 1 & Model 2 & Model 3 & Model 4 & Model 5 \\
\hline 1.5 Generation & -.1084677 & $.9813337 * \star \star$ & $.9467308 * * *$ & $.31447 \star \star \star$ & $.5013234 * \star \star$ \\
\hline \multicolumn{6}{|c|}{ Race (reference $=$ White) } \\
\hline Hispanic & $-.2145833 * \star *$ & $-.2353379 * \star \star$ & $-.2482415^{\star}$ & $.8748676 * \star \star$ & $.8811072 * \star \star$ \\
\hline Black & $-.2013799 * \star \star$ & $-.2009689 * * \star$ & $-.2047288 * \star \star$ & $-.153596 * \star$ & $-.1550762 \star \star$ \\
\hline Asian & $.3421665 * * *$ & $.3196499 * \star \star$ & .3376508 & $1.681314 * \star \star$ & $1.863359 * \star \star$ \\
\hline Other & $.4817465 \star \star \star$ & $.4755689 * \star \star$ & $.4661008 * \star \star$ & $.6946748 * \star \star$ & $.6839764 \star \star \star$ \\
\hline \multicolumn{6}{|c|}{ Age Cohort (reference $=30 \mathrm{~s}$ ) } \\
\hline $20 \mathrm{~s}$ & $.5304554 \star \star \star *$ & $.5362887 \star \star \star$ & 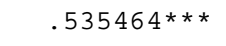 & $.5302907 \star \star \star$ & $.5303057 \star \star \star$ \\
\hline $40 \mathrm{~s}$ & $-.601851 * \star \star$ & $-.6028148 * \star \star$ & $-.6023658 * \star \star$ & $-.6023232 * \star \star *$ & $-.6024264 * \star \star$ \\
\hline $50 \mathrm{~s}$ & $-.8957603 * \star *$ & $-.8976007 * \star *$ & $-.8975725 * \star \star$ & $-.8976187 \star \star \star$ & $-.8977484 * \star \star$ \\
\hline $60 s$ & $-.9267828 * \star \star$ & $-.929212 \star \star \star$ & $-.9288065 * \star \star$ & $-.930464 * \star \star *$ & $-.9305598 * \star \star$ \\
\hline $70 \mathrm{~s}$ & 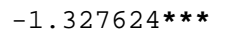 & $-1.332867 * \star \star$ & $-1.331437 * \star \star$ & $-1.343017 \star \star \star$ & $-1.34312 \star \star \star$ \\
\hline \multicolumn{6}{|c|}{ Education (reference= HS Diploma) } \\
\hline$<\mathrm{HS}$ & $-.1073609 * \star *$ & $-.1035471 * \star \star$ & $-.1065131 * \star \star$ & $-.1318376 * \star$ & $-.1315131 * \star$ \\
\hline College & $.4052841 * \star \star$ & $.3973532 * \star *$ & $.3930028 * \star \star$ & $.6573508 * * *$ & $.6571282 * \star \star$ \\
\hline $\mathrm{BA}+$ & $.9017325 \star \star \star$ & $.8905986 * \star \star$ & $.8896476^{* * *}$ & $1.418507 * \star \star$ & $1.418238 * \star \star$ \\
\hline \multicolumn{6}{|l|}{ Other Variables } \\
\hline Self-Employed & $-.4253146 \star \star \star$ & $-.4272307 \star \star \star$ & $-.4275826 * \star \star$ & $-.42314 * * \star$ & $-.4230711 * \star \star$ \\
\hline Married & $.0186823 \star \star \star *$ & $.0217397 \star \star \star$ & .0197272 & .0223549 & .0224067 \\
\hline Female & $-.1244014 * \star \star$ & $-.1254112 * \star \star$ & $-.1232799 * \star \star$ & $-.1247187 * \star \star$ & $-.1247094 * \star \star$ \\
\hline \# persons in hhold & $-.1180052 \star \star \star *$ & $-.117566 * \star \star$ & $-.1178748 * * *$ & $-.1192422 * \star \star$ & $-.119252 * \star \star$ \\
\hline \multicolumn{6}{|l|}{ Origin Variables } \\
\hline Logcon & & $.0481467 \star \star \star$ & $.0570917 \star$ & $.2773517 \star \star \star$ & $.2778868 * \star \star$ \\
\hline $1.5 \cdot \operatorname{con}$ & & $-.481298 * \star \star$ & $-.4604138 * \star *$ & $-.1675394 * \star \star$ & $-.2661558 * \star \star$ \\
\hline Empchange & & & $.010611 * \star$ & $.0096534 *$ & $.0096216 *$ \\
\hline$\%$ manufacturing & & & -.5421331 & -.3685828 & -.3669636 \\
\hline \multicolumn{6}{|c|}{ 2nd-order race-concentration-interactions } \\
\hline Hisp·con & & & & $-.5612732 * \star \star$ & $-.5645015 * \star \star$ \\
\hline Black·con & & & & -.0376323 & -.0366507 \\
\hline Asian·con & & & & $-.6319879 * \star \star$ & $-.7235271 \star \star \star$ \\
\hline Other·con & & & & $-.1480317 * \star$ & $-.1413068 *$ \\
\hline \multicolumn{6}{|c|}{ 2nd-order education-concentration interactions } \\
\hline$<\mathrm{HS} \cdot \mathrm{con}$ & & & & .0221714 & .0219958 \\
\hline College·con & & & & $-.1802401 * \star \star$ & $-.1801307 * \star \star$ \\
\hline BA·con & & & & $-.3488874 * \star \star$ & $-.3487475 * \star \star$ \\
\hline \multicolumn{6}{|c|}{ 2nd-order 1.5 generation-race interactions } \\
\hline 1.5·Hisp & & & & .0510559 & -.1887711 \\
\hline 1.5•Black & & & & $.3186858 \star \star \star$ & $.612174 * \star \star$ \\
\hline 1.5·Asian & & & & .0039775 & $-.7403855 * \star \star$ \\
\hline 1.5.Other & & & & $.201944 \star \star$ & $.7267341 * \star \star$ \\
\hline \multicolumn{6}{|c|}{ 3rd-order 1.5 generation-race-concentration interactions } \\
\hline 1.5·Hisp·con & & & & & .122797 \\
\hline 1.5·Black·con & & & & & -.1241049 \\
\hline 1.5-Asian-con & & & & & $.3784466 * \star \star$ \\
\hline $1.5 \cdot$ Other $\cdot$ con & & & & & $-.2469316^{\star}$ \\
\hline Constant & $-2.036241 * \star \star$ & $-2.104456 * \star \star$ & $-2.11797 * \star \star$ & $-2.43644 \star \star \star$ & $-2.437172 \star \star \star$ \\
\hline
\end{tabular}

${ }^{*} p<0.1 ;{ }^{* *} p<0.05 ;{ }^{* \star *} p<0.01$ 


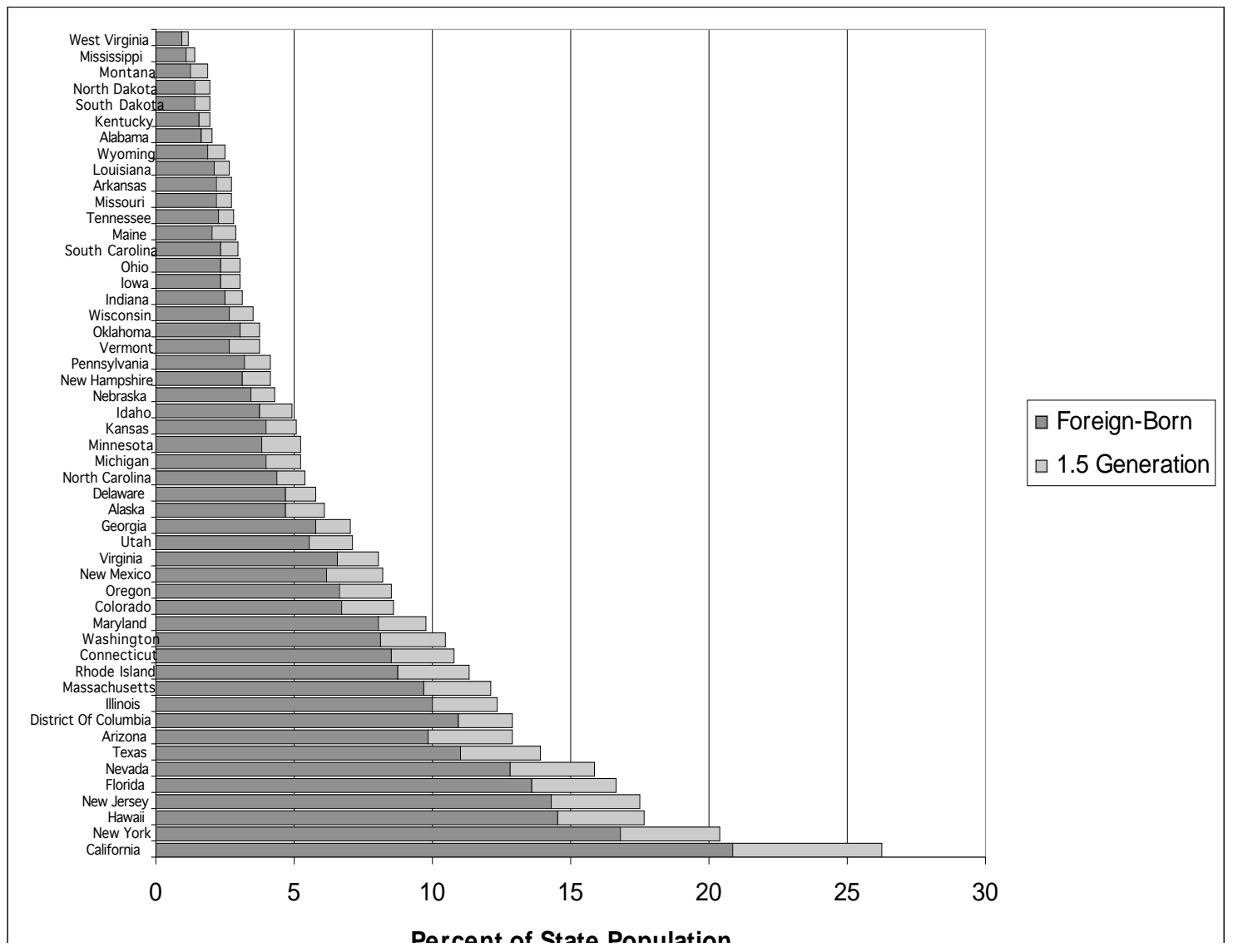

Figure 1 - State Foreign-Born and 1.5 Generation Population Shares

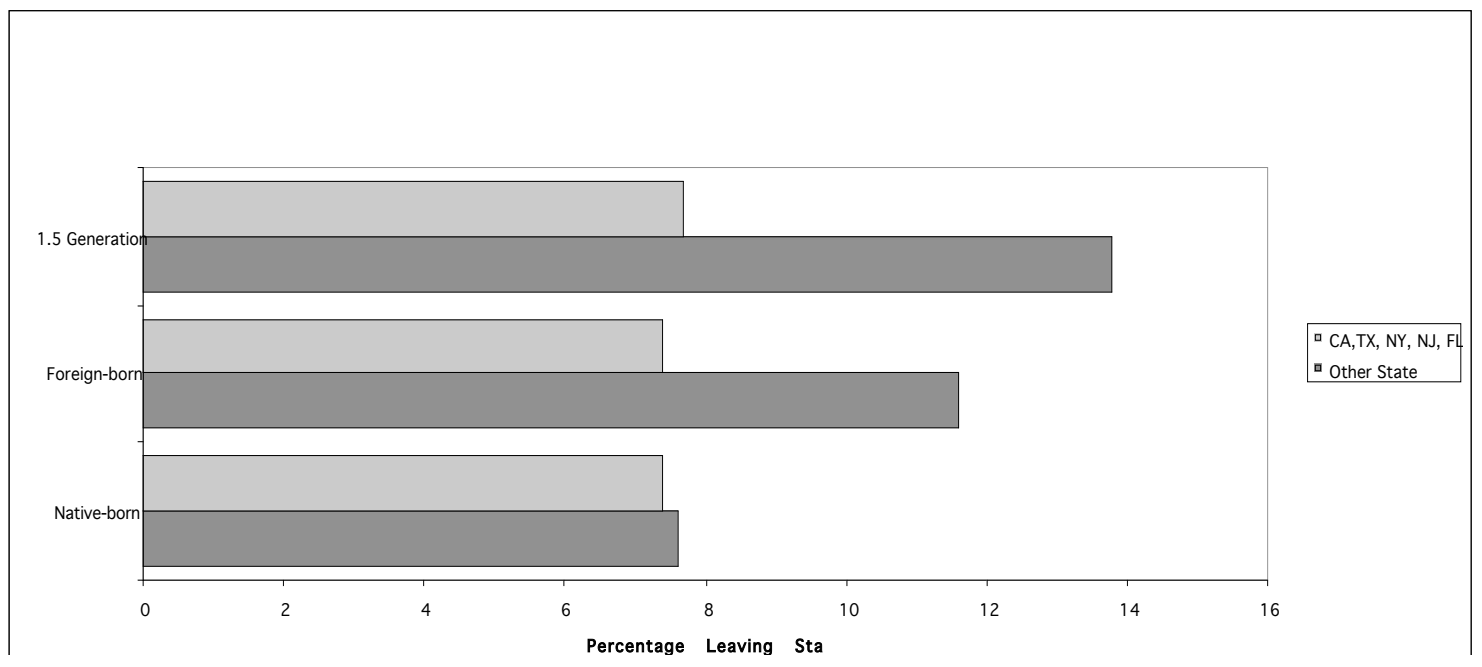

Figure 2 - Nativity and Inter-State Migration Rates 


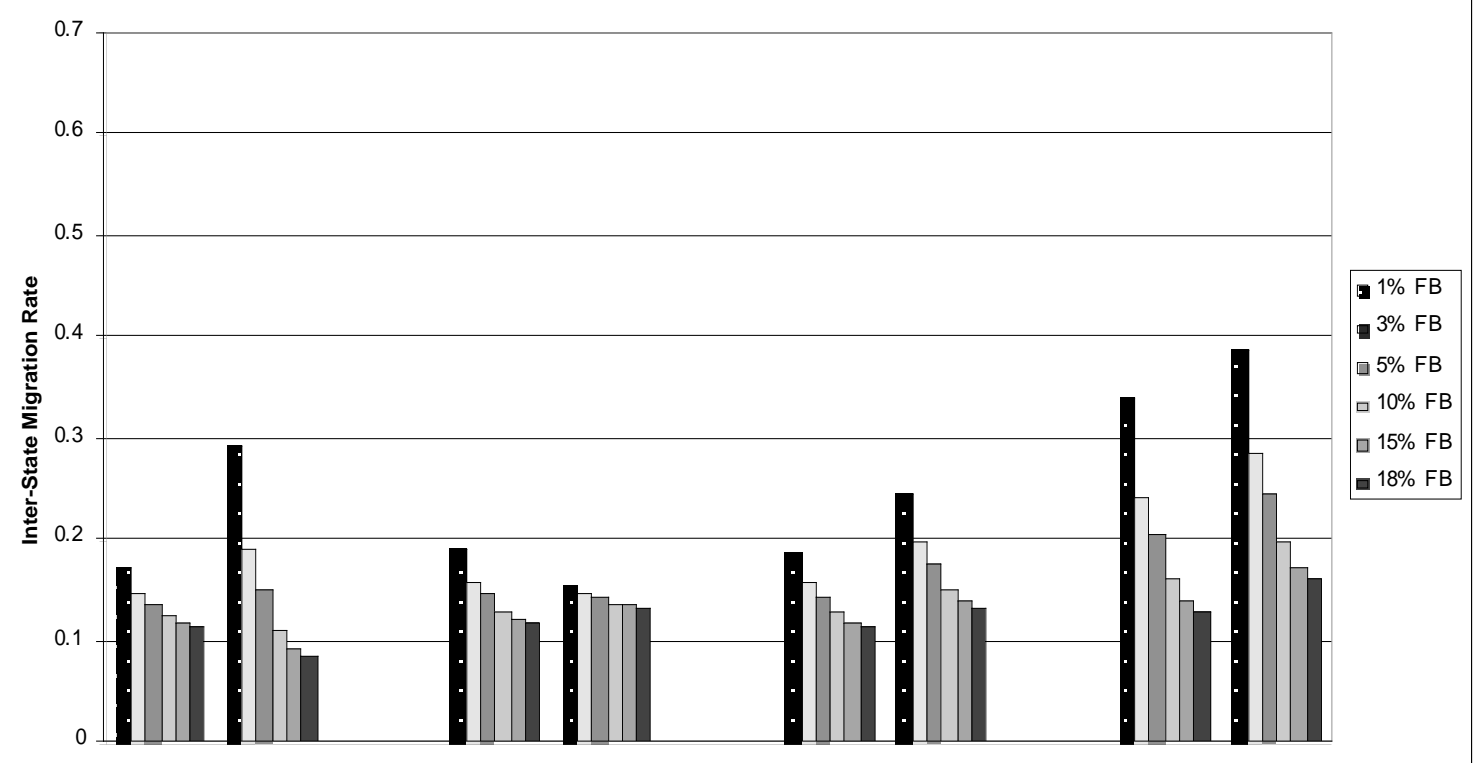

Figure 3 - Probabilities of Interstate Migration for the High School-Educated by Foreign-Born Concentration: Foreign-Born/1.5 Generation Models

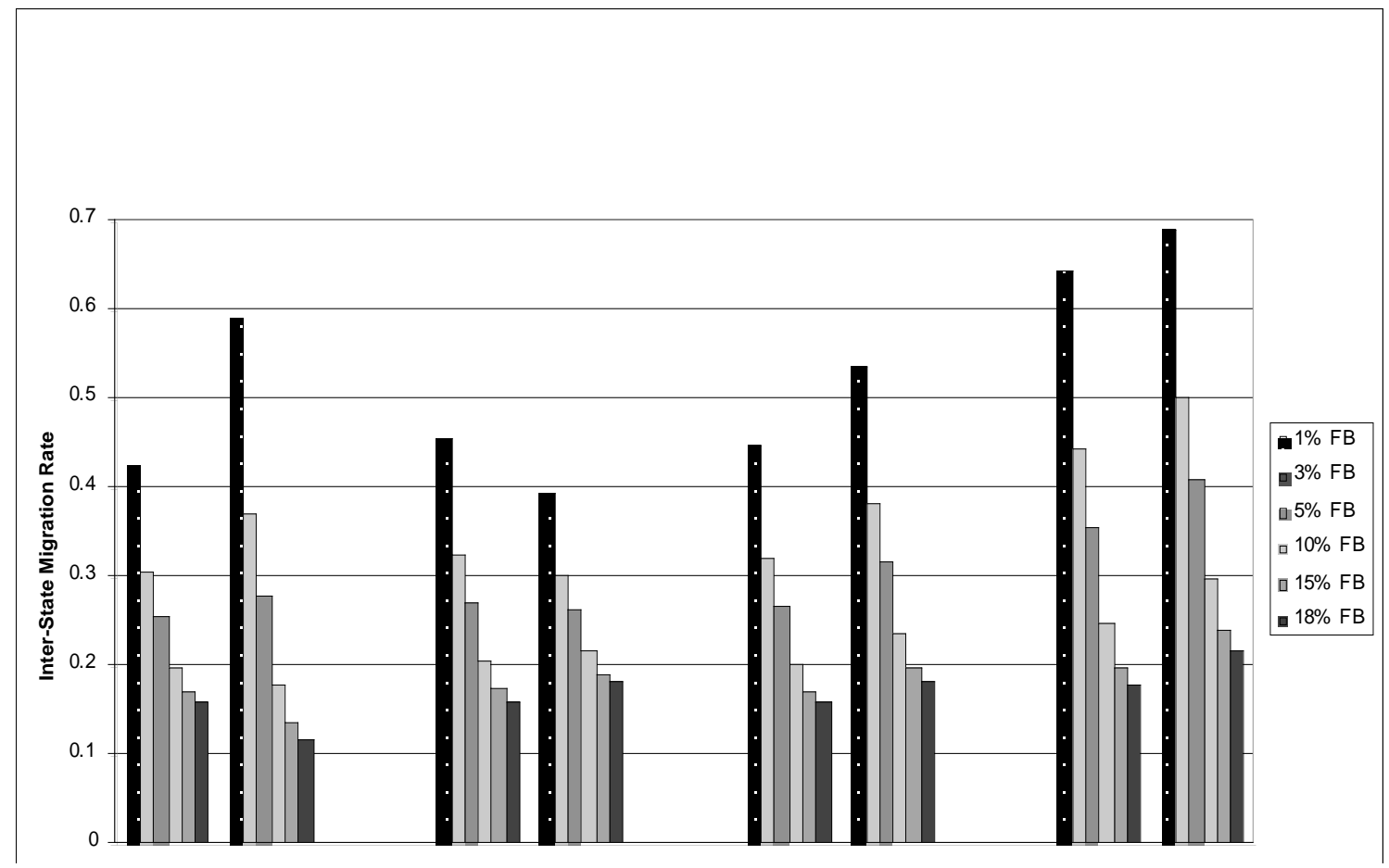

Figure 4 - Probabilities of Inter-State Mobility for BA Recipients by Foreign-Born Concentration: : Foreign-Born/1.5 Generation Models 


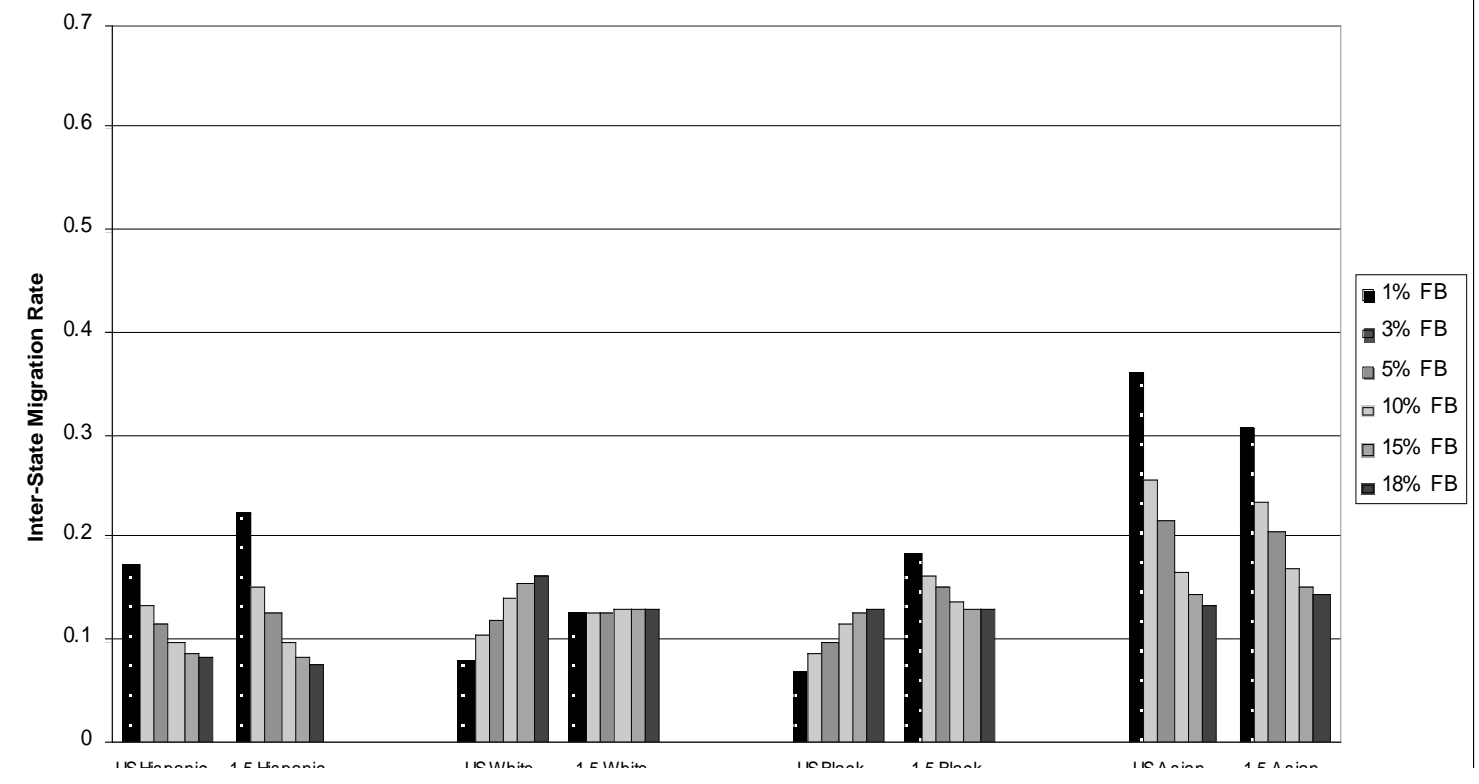

Figure 5 - Probabilities of Interstate Migration for the High School-Educated by Foreign-Born Concentration: US-Born/1.5 Generation Models

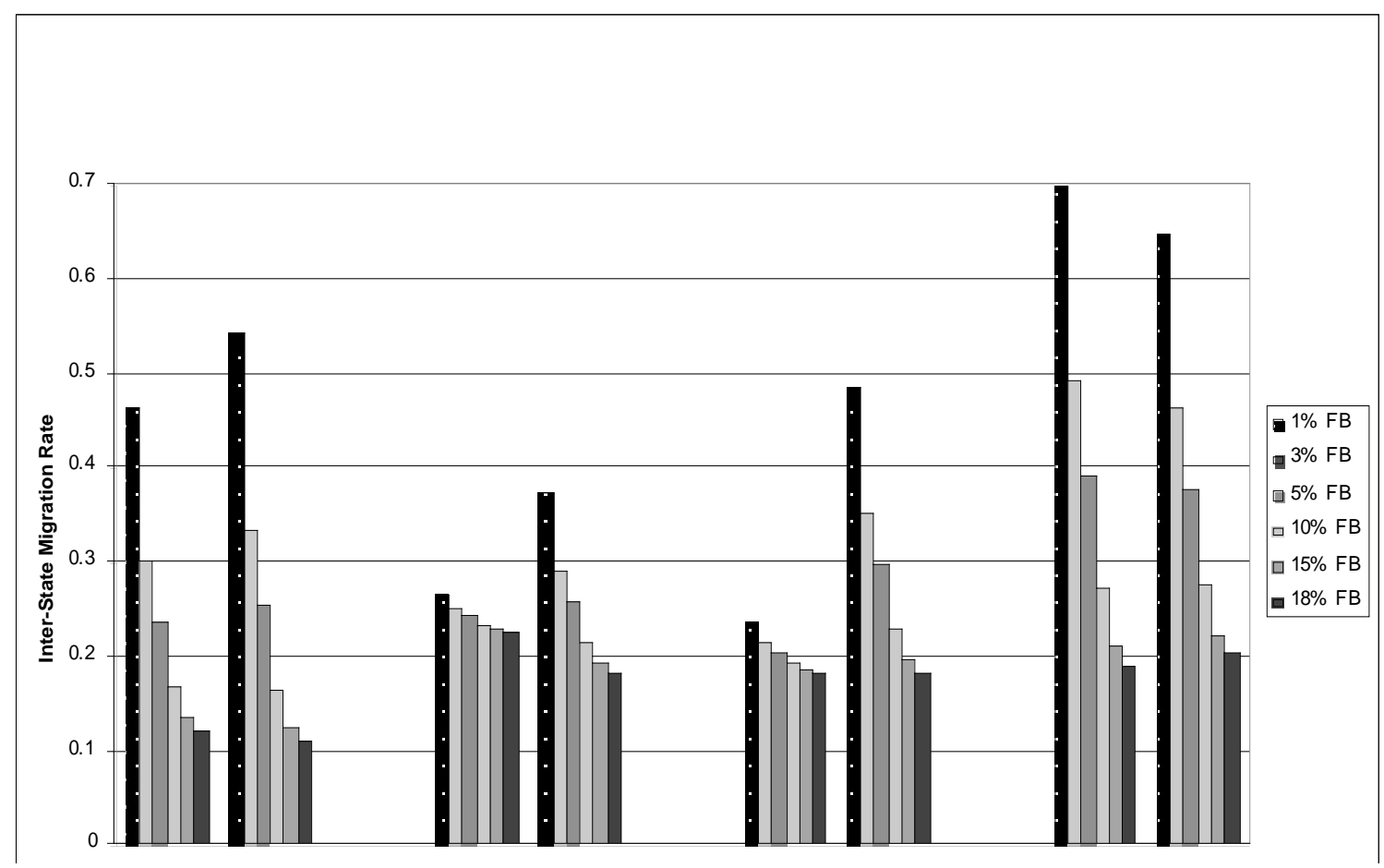

Figure 6 - Probabilities of Inter-State Mobility for BA Recipients by Foreign-Born Concentration: US-Born/1.5 Generation Models 